ROCZNIKI HUMANISTYCZNE

Tom LXVI, zeszyt $11-2018$

ZESZYT SPECJALNY/SPECIAL ISSUE

DOI: http://dx.doi.org/10.18290/rh.2018.66.11s-2

ARTUR BLAIM

\title{
SUPERHUMANS, TRANSHUMANS, AND POSTHUMANS IN EARLY MODERN UTOPIAN FICTION
}

\begin{abstract}
A bstract. The paper analyses the functioning of transhumanist and posthumanist motifs in Renaissance and Enlightenment utopias which invariably foreground the natural enhancement of human mental and physical capabilities not only by ideal social and political conditions, but also education, improved diet, healthy and moral lifestyle. New technologies and inventions may contribute to the comforts of life, but ultimately do not alter the traditional model of humanity. Occasionally introduced transhuman and posthuman creatures do not constitute models of the future development of humanity, functioning only as satirical elements, or as devices increasing the sensational appeal of the works in which they appear.
\end{abstract}

Keywords: early modern utopian fictions; humanism; transhumanism; posthumanism.

Whilst it might seem somewhat inappropriate to apply retrospectively or anachronistically the concepts of transhumanism or posthumanism ${ }^{1}$ to the early modern period, it is nevertheless possible to identify examples of anticipations and quasi-anticipations as well as analogies and pseudo-analogies, apart from evident, even though sometimes functionally different, individual cases of similarities, or even identities. Indeed, Nick Bostrom, the leading theorist of transhumanism, maintains that some of the key ideas of transhumanism such as human perfectibility and the idea of progress advanced in his "Letter from Utopia" and other writings have their roots in the Renaissance and Enlightenment, sharing many characteristics with utopias and utopianism. $^{2}$

Prof. ARTUR Blaim - University of Gdańsk, Faculty of Languages, Institute of English and American Studies; address for correspondence: ul. Wita Stwosza 51, 80-308, Gdańsk; e-mail: angab@ug.edu.pl

${ }^{1}$ For a relevant discussion of the concepts of transhumanism and posthumanism see i.a. Wolfe (2010), Roden (2015), or Hauskeller (2016).

${ }^{2}$ See Bostrom 2005: 1-25. 
All Renaissance and Enlightenment utopias invariably put strong emphasis on the natural enhancement of human mental and physical capabilities not only by creating an ideal natural, social and political environment, but also through education, improved diet, healthy and highly moral lifestyle. The idea of optimizing human potential is foregrounded already in Thomas More's Utopia (1516), particularly in Hythlodaeus's account of the origins of the ideal state: "Utopus [...] brought the rude and rustic people to such a perfection of culture and humanity as makes them now superior to almost all other mortals" (113). An ideal social, political and natural environment cannot but produce ideal people, about whom Hythlodaeus exclaims: "you had never seen a well-ordered people anywhere but there" (107), especially when permanent education is offered to all citizens. The narrator of Francis Bacon's New Atlantis (1627) goes even further in his enthusiasm: "there is not under the heavens so chaste a nation as this of Bensalem, nor so free from all pollution or foulness" to the extent that "[i]t is the virgin of the world," as "there is nothing, among mortal men, more fair and admirable than the chaste minds of this people" (173). In Francis Godwin's Man in the Moone (1638), the lunars "all, young and old doe hate all manner of vice, and doe live in such love, peace, and amitie, as it seemeth to be another Paradise," whereas their females are "all of an absolute beauty" (104); the Sevarambians are "the soberest people of the World, free from all those wild passions which cause so much disturbance in other Lands" (Veiras, 64); the Geranians "are all naturally healthful, streight Bodied, all Honest and Generous, all affable and Religious" (Barnes 80); the inhabitants of Heliopolis are "so regular and just, that the Age of Gold may seem to continue stil among them" (L'Epy 175); those of the Island of Content "are an amicable People, who, together and apart, study our King's Ease, the publick Safety, and our own Happiness" (Anonymous, The Island of Content 20). The inhabitants of the underground Central World "resemble angels rather than men," which can hardly be surprising, considering that "nothing but Friendship, Hospitality, and a brotherly Affection to all their Fellow-Creatures, reigns in this Happy World" (Anonymous, A Voyage to the World in the Centre of the Earth 62); the Soterians are "such Christians, as [...] are not to be paralleled by any particular Church at this time in the known World" (Kirkby 5); the Veritasians are "a lively cheerful people," "strictly virtuous," and "truly religious;" following "the dictates of regulated nature," and turning "all their passions to a proper and happy course" (Anonymous, The Island of Veritas 19); the Bonhommicans are a brave, generous and virtuous 
people, being in possession of a sixth, moral sense (Elliott 213). The male Children of Love are "of perfect symmetry," and their eyes express "a perfect awe and majesty in them" (Evans 70), while the females are "extremely beautiful, both as to face and shape," "their limbs exactly proportion'd, without any deformity among them" (75). Makarian women are not only chaste but also "handsome and well-educated" (Northmore 133). The Mezzoranians are described as "the handsomest Race of People I believe Nature ever produced," as their features are "the most exact and regular imaginable," the men "universally well shaped, tall and slender," and the women "the most beautiful Creatures, and the best shaped in the World" (Berington 180).

Occasionally, primitive eugenic methods are made to assist the most favourable social, political and natural environment in producing the best possible human beings. These methods range from a simple by-product of mutual physical satisfaction - as in More's Utopia, where the prospective husband and wife inspect each other naked accompanied by a "worthy and respectable matron" and "a discreet man," or, as in New Atlantis that has special places appointed for that purpose: "because of many hidden defects in men and women's bodies [...], they have near every town a couple of pools, (which they call Adam and Eve's pools,) where it is permitted to one of the friends of the men, and another of the friends of the woman, to see them severally bathe naked" (Bacon 175) — to the most complex system functioning - as in Tomasso Campanella's City of the Sun (1602):

\begin{abstract}
Tall handsome girls are not matched with any but tall brave men, while fat girls are matched with thin men and thin girls with fat ones, so as to avoid extremes in their offspring. [...] Nor may they have intercourse until they have completely digested their food and have said their prayers. There are fine statues of illustrious men that the women gaze upon. [...] The officials, all of whom are priests, and the learned do not try to procreate without first submitting to numerous conditions and restrictions stretching over many days. The reason for this is that those who are much given to speculation tend to be deficient in animal spirits and fail to bestow their intellectual powers upon their progeny because they are always thinking of other matters. Thus they produce offspring of poor quality. As a consequence, they take care to mate with energetic, spirited handsome women. Men who have a flighty, capricious disposition are matched with women who are fat, even-tempered, and gentle. (57)
\end{abstract}

A different eugenic system operates among the gigantic lunars in Francis Godwin's The Man on the Moone, where those "who are likely to bee of a wicked or imperfect disposition" are sent to the Earth" (104). 
In most utopias, there occurs strict matching of moral and physical excellence, with the latter performing the role of a signifier of the former. However, and this constitutes the most striking difference between contemporary transhumanism and early modern utopias, any artificial enhancement of physical attributes, even in connection with such seemingly inessential aspects as external appearance, is condemned as contrary to nature: from deploring "disgraceful affectation" or "painted beauty" in Utopia (More 193) and prohibiting the cutting of long beards in Sevarambia (Veiras 75), to regarding as a subversive activity, apparently undermining the foundations of the ideal state in the City of the Sun, where "It is a capital offense for women to use cosmetics, [...] or to wear high heels and gowns with trains to cover the heels (61). Physical and moral beauty is invariably accompanied by perfect health and longevity, to the extent that all kinds of diseases and even their minor manifestations, such as vomiting and spitting, turn into signs of "inactivity, laziness, or gluttony" (91). In the land of Severambians all bodily imperfections are symptoms of moral corruption, and those afflicted by them are removed to the spatial margins of the ideal society: "all the disorderly persons, the lecherous, the filthy, and base, each sort have their distinct places of abode, or Islands, from whence they are not suffered to depart till they dye naturally" (Veiras 68).

At the same time, longevity that results from crossing the bounds of what is deemed natural can generate only monstrosity. When Lemuel Gulliver learns of the immortal Struldbruggs he responds with a utopian vision of their lives and the society blessed with their presence:

Happy Nation, where every Child hath at least a Chance for being immortal! Happy People, who enjoy so many living Examples of ancient Virtue, and have Masters ready to instruct them in the Wisdom of all former Ages! but happiest, beyond all Comparison, are those excellent Struldbruggs, who, being born exempt from that universal Calamity of human Nature, have their Minds free and disengaged, without the Weight and Depression of Spirits caused by the continual Apprehension of Death. (Swift 178)

However, as he is soon to learn, upon reaching the old age the immortals begin to lead a truly dystopian existence: ${ }^{3}$

When they came to Fourscore Years, which is reckoned the Extremity of living in this Country, they had not only all the Follies and Infirmities of other old Men, but many more which arose from the dreadful Prospect of never dying. They were not only opinionative, peevish, covetous, morose, vain, talkative; but uncapable of

\footnotetext{
${ }^{3}$ For an extensive discussion of the role of monstrosity in the rise of dystopian discourse see Claeys 58-112.
} 
Friendship, and dead to all natural Affection, which never descended below their Grand-children. Envy and impotent Desires are their prevailing Passions. [...] At Ninety they lose their Teeth and Hair; they have at that Age no Distinction of Taste, but eat and drink whatever they can get, without Relish or Appetite. The Diseases they were subject to still continue without increasing or diminishing. [...] They were the most mortifying Sight I ever beheld; and the Women more horrible than the Men. Besides the usual Deformities in extreme old Age, they acquired an additional Ghastliness in Proportion to their Number of Years, which is not to be described [...]. (Swift 181-183)

The only example of a positive representation of "unnaturally" enhanced faculties, bypassing all race, gender and species boundaries, can be found in Margaret Cavendish's utopian work The Blazing World (1666), perhaps the first attempt to present an approximation of a posthuman society in utopian fiction. Unlike earlier imaginary voyages in which distant lands were sometimes inhabited by monstrous creatures combining human and non-human features, such as those in Lucian's True History, the Blazing World's hybrid inhabitants form an ideal uniform society with its human members:

Their Priests and Governors were Princes of the Imperial Blood, and made Eunuches for that purpose; and as for the ordinary sort of men in that part of the World where the Emperor resided, they were of several Complexions; not white, black, tawny, olive or ash-coloured; but some appear'd of an Azure, some of a deep Purple, some of a Grass-green, some of a Scarlet, some of an Orange-colour, \&c. [...] The rest of the Inhabitants of that World, were men of several different sorts, shapes, figures, dispositions, and humors, [...] some were Bear-men, some Worm-men, some Fish- or Mear-men, otherwise called Syrens; some Birdmen, some Fly-men, some Ant-men, some Geese-en, some Spider-men, some Lice-men, some Fox-men, some Ape-men, some Jack daw-men, some Magpiemen, some Parrot-men, some Satyrs, some Gyants, and many more, which I cannot all remember [...]. (Cavendish 14-15)

In certain respects they surpass the humans because their hybrid nature provides them with special skills and abilities which the Empress makes use of in her efforts to acquire the fullest possible knowledge of the universe: "The Bear-men were to be her Experimental Philosophers, the Bird-men her Astronomers, the Fly- Worm- and Fish-men her Natural Philosophers, the Ape-men her Chymists, the Satyrs her Galenick Physicians, the Fox-men her Politicians, the Spider- and Lice-men her Mathematicians, the JackdawMagpie- and Parrot-men her Orators and Logicians, the Gyants her Architects, \&c" (Cavendish 15-16). Despite the heroine's apprehensions upon her first encounter with them there is no question of their monstrosity as the hybrid creatures are endemic to the Blazing World. 
In all other contexts interspecies intercourse generates monstrosity, as in the case of the inhabitants of an underground cave in Ralph Morris's The Life and Astonishing Adventures of John Daniel (1770), the unhappy offspring of a shipwrecked woman's sexual relationship with a sea-monster. ${ }^{4}$ However, when the other species exhibits predominately human features, the situation is altogether different. In Adolpus Bannac's The Life and Surprizing Adventures of Crusoe Richard Davis (1756), the civilising process instigated by the European protagonist eradicates the initial monstrosity of the feathered natives who "scarce know what recumbancy is, except in sickness and procreation; for they rest standing upon the bare ground, in the most severe seasons, and that in the open air too; but most frequently in the woods, sometimes half buried in snow; and thus, in the depth of winter, would they remain for weeks together, without motion, unless disturbed" (II: 12).

A slightly more complicated case appears in Robert Paltock's The Life and Adventures of Peter Wilkins (1751), where the Glumms and Gawreys are equipped with an additional part of the body called the graundee, which, according to need, can be used as clothing, wings or boat. However, these extraordinary attributes, being the work of nature, do not imply the superiority of the natives or their mode of life but, on the contrary, point to their inferiority in being dependent only on what nature provides. Their ability to fly is superseded by Peter's intellectual abilities and civilised skills enabling him to make clothes, produce a boat, or contrive a device to carry him into the air.

\footnotetext{
${ }^{4}$ The motif of (potential) trans-species sexual relations appears in Book IV of Gulliver's Travels, when Gulliver is almost raped by a female Yahoo: "Being one Day abroad with my Protector the Sorrel Nag, and the Weather exceeding hot, I entreated him to let me bathe in a River that was near. He consented, and I immediately stripped myself stark naked, and went down softly into the Stream. It happened that a young Female Yahoo, standing behind a Bank, saw the whole Proceeding, and inflamed by Desire, as the Nag and I conjectured, came running with all Speed, and leaped into the Water, within five Yards of the Place where I bathed. I was never in my Life so terribly frightened. [...] She embraced me after a most fulsome Manner. I roared as loud as I could, and the Nag came galloping towards me, whereupon she quitted her Grasp, with the utmost Reluctancy, and leaped upon the opposite Bank, where she stood gazing and howling all the time I was putting on my Clothes (Swift 232-233). A similar situation occurs in A Voyage to Cacklogallinia, where the protagonist rejects the amorous advances of human-sized hens: "Her Grace was as generous as her Spouse; and when I urg'd the Difference of our Species, she said, she was satisfied that wou'd be no Impediment, by what she had seen, for I had indeed no other Covering than a Mantle, and both his Majesty and his Squabbaws took a Pleasure to teaze me, by pulling it off, and leaving me naked in a full Circle. In short, I was forc'd to save my self by the Window being on a Ground Floor, after all my Excuses were to no Purpose" (Anonymous. A Voyage to Cacklogallinia 71). Both these episodes exhibit mainly the satirical function by presenting a grotesquely distorted image of the immoral conduct of upper class ladies ( $A$ Voyage to Cacklogallinia) and women in general (Gulliver's Travels).
} 
In Gabriel de Foigny's A New Discovery of Terra Incognita Australis, the natives are hermaphrodites, which for the narrator raises questions of humanness, perfection, and monstrosity. From the perspective of the narrator, incidentally a hermaphrodite himself, but representing the standard European point of view, "such as happen'd to be born so" are considered Monsters, according to the logic that "a Being was perfect when it wanted nothing that Constituted its Nature, and that therefore to add to it what good things another possest, would not render it more perfect, but rather make it Monstrous" (67). The counterargument offered by his Australian interlocutor rests on the assumptions that "to be Man it is necessary to be entire and compleat" (67) and that "the more perfect a Being is the less need it has of any Assistance from without" (70). Since "both Sexes are necessary for the perfection of an entire Man," "those who have but one [sex]" not simply are imperfect but can only be regarded as half-Men, an intermediary stage between beasts and humans (68). This is perhaps the most radical expression of the standard critique of Europeans as inferior beings by the inhabitants of utopian lands.

None of the utopian societies in the early modern period comes close to the radical posthumanist anti-anthropocentrism that rejects human supremacy and species hierarchy in favour of "the relational capacity of the postanthropocentric subject" that is "not confined within our species, but it includes non-anthropomorphic elements: the nonhuman, vital force of Life," which Rosi Braidotti calls "zoe," characterizing it as "the transversal force that cuts across and reconnects previously segregated species, categories and domains" (22). ${ }^{5}$ Although in A Voyage to the World in the Centre of the Earth, the animals are granted the status of cohabitants ("next after worshipping and adoring our Creator, it is the principal Part of our Religion to protect what he has been pleased to give Life to" [48]), they do not form a single society with the humans, despite being in possession of souls and numerous other admirable characteristics, as the utopian guide explains to his guest from England:

You allow none but yourselves to have Reason, the more Shame for you, when those (which you unjustly call the Brute Creation) exceed you so far. Must it not be paying yourselves a bad Compliment, to say you are the only rational Part of the Creation, and at the same Time perceive, what you call Brutes behave with infinite[ly] more Reason than yourselves? whilst one of your own Species shall behave in a Manner inconsistent with all Reason? In what manner does that Part (which you call the Brute Creation) behave inconsistently with Reason? is it

\footnotetext{
${ }^{5}$ See Braidotti 2016: 22.
} 
shewn by the Ant, who lays up for Winter, whilst the Spendthrift squanders all To-Day and starves To-morrow? Is it in the Beaver, whose Skill in Architecture exceeds the fam'd Inigo himself? Is it in the Bee, whose Works infinitely surpass those of any of your rational Beings, and whose Armies are better conducted than yours, by your most famous Generals? The very Spider provides itself a House, whilst your rational Beings are starving for want of a Covering to their Heads. The Young of any Species as soon as deliver'd from their Dam, have Sense to avoid what is hurtful. Is it so with the Young of your rational Beings? Your Children, till they are a Year old or more, are mere Idiots, and would as soon grasp a flaming Candle as a Rattle. Is it Reason? (Anonymous, A Voyage to the World in the Centre of the Earth 50-51)

Without going that far, several other utopian societies also exhibit an evident tendency to at least mitigate the inferior status of animals, either eliminating meat from their diet altogether, or radically restricting its use: on the Island of Content, no meat is allowed "because we look upon it as sinful to destroy one of God's Creatures for the Preservation of another" (Anonymous, The Island of Content 6); the Makarians live mostly on fruit, with very little animal food "for the most part consumed in soups" (Northmore 19); for the Noiblans "every third Day Flesh-Meat is allowed but in a small, limited Quantity" (Gentleman 37), for the Selenites "eating any thing that has had Life, is look'd upon with Abhorrence, and never known in this World" (Anonymous, A Voyage to Cacklogallinia 148).

When the ideal worlds are literally "posthuman," in the sense that they are inhabited either by spiritual entities or beings in the transitory stage between the end of their earthly existence and afterlife, they constitute an entirely distinct domain from the human world and as such they offer no model to be applied in the real world. In Thomas Lupton's Siuqila (1580), the European visitor's interlocutor forcefully declares the peculiar mode of existence of his country and its inhabitants: "I am called OMEN, and my Country is called Mauqsun, therefore the place is not meete for you to be in, unlesse you can lyue foodelesse, (I had almost sayd faultlesse)" (8). A more complex ontological status is assigned to the inhabitants of the Moon depicted in A Voyage to Cacklogallinia, who are characterised as "neither corporeal, nor an aerial Substance, but (I know not how otherwise to express myself) between both" (142). The narrator's host offers further explanation, identifying the inhabitants as representing the posthuman phase preceding the otherworldly one:

But that I may give you some Idea, both of this World, and its Inhabitants, you must learn, that Men in yours are endued with a Soul and an Understanding; the Soul is a material Substance, and cloathes the Understanding, as the Body does the Soul; at the Separation of these two, the Body is again resolved into Earth, and 
the Soul of the Virtuous is placed in this Planet, till the Understanding being freed from it by a Separation we may call Death [...]. We have not here, as in your World, Distinction of Sexes; for know, all Souls are masculine [...] however distinguish'd in the Body (Anonymous, A Voyage to Cacklogallinia 149-151)

Consequently, the ideal world on the moon is essentially inaccessible to "normal" human beings, even though, unlike the world beyond the grave, it enjoys a quasi-material mode of existence: "it was never known, that gross Flesh and Blood ever before breath'd this Air, and that your Stay may be fatal to you, and disturb the Tranquillity of the Selenites (Anonymous, A Voyage to Cacklogallinia 155)."

In the early modern utopian fictions, human perfectibility is invariably kept within the confines of what is regarded as limitations imposed by God and nature, the position most strongly articulated by Swift in Gulliver's Travels where all attempts at transcending natural restrictions are either ridiculed as nonsensical (The Academy of Lagado) or undesirable (the Struldbruggs episode). Technological inventions, even such extraordinary ones as those produced by members of the Solomon's House in Bacon's New Atlan$t i s$, can at best be seen as useful contributions to improving the comforts of life, but ultimately do not alter in any way the traditional view of humanity. ${ }^{6}$ The occasionally appearing transhuman and posthuman creatures function not as models of future development of humans and human society but, at most, as entertaining devices that heighten the sensational appeal of the fictions in which they appear and at the same time reduce their potential applicability in reality. On the other hand, the introduction of such motifs and their association with the notion of human perfectibility foreshadows many aspects of what in recent years came to be called transhumanism.

\footnotetext{
${ }^{6}$ The same holds true of Charles Dibdin's Hannah Hewit (1796), one of the few English robinsonade-utopias in which the enterprising protagonist produces a robot in the image of her husband: "The principal I went upon was that of a musical clock, which utters open sounds through the medium of pent air conveyed occasionally into different pipes. [...] I presently taught my figure a variety of interjections. He would cry out $\mathrm{Oh}$, ah, humph, as correctly as a critic who was asked if he recollected a particular beauty in Shakespeare; I made him sigh as naturally as a self approving Adonis who expected you to fall in love with him; he would whistle as vacantly as a dashing fellow who had just received a useless admonition from his injured father; and he would laugh as triumphantly as an impudent rake who had just put modesty to the blush. When I had brought my contrivance to this I selected a few words, that by transposition and retransposition would form different sentences; and by this method, this kind of anagram in language, I made my figure converse pretty well. (Hannah Hewit II: 93-95).
} 


\section{WORKS CITED}

Anonymous. A True and Faithful Account of the Island of Veritas; Together with the Forms of Their Liturgy; and a Full Relation of the Religious Opinions of the Veritasians, as Delivered in Several Sermons Just Published in Veritas. London, 1790.

Anonymous. A Voyage to Cacklogallinia with a Description of the Religion, Policy, Customs and Manners of that Country. By Captain Samuel Brunt. London, 1727.

Anonymous. A Voyage to the World in the Centre of the Earth. London, 1755.

Anonymous. The Island of Content; or, A New Paradise Discovered. London, 1709.

Bacon, Francis, New Atlantis, in Susan Bruce (ed.), Three Early Modern Utopias. Thomas More: Utopia / Francis Bacon: New Atlantis / Henry Neville: The Isle of Pines. Oxford: Oxford University Press, 1999. 149-186. Print.

[Bannac, Adolphus]. The Life and Surprizing Adventures of Crusoe Richard Davis. London, 1756.

Barnes, Joshua, Gerania: A New Discovery of a Little sort of People Anciently Discoursed of, called Pygmies. London, 1675.

[Berington, Simon]. The Memoirs of Signor Guadentio di Lucca. Taken from his Confession and Examination before the Fathers of the Inquisition at Bologna in Italy. Making a Discovery of an Unknown Country in the Midst of the Vast Deserts of Africa, as Ancient, Populous, and Civilized, as the Chinese. With an Account of their Antiquity, Origine, Religion, Customs, Polity, \&c. and the Manner how they got first over those vast Deserts. London, 1737.

Bostrom, Nick. "Letter from Utopia." 2010: n. pag. Web.

Bostrom, Nick. "A History of Transhumanist Thought." Journal of Evolution and Technology 14 (1) 2005. 1-25. Print.

Braidotti, Rosi. "Posthuman Critical Theory." Critical Posthumanism and Planetary Futures. D. Banerji and M.R. Paranjape (eds.). New Delhi: Springer India, 2016. Print.

Cavendish, Margaret. The Description of a New World, Called the Blazing World. London, 1666.

Claeys, Gregory. Dystopia. A Natural History. Oxford: Oxford University Press, 2017. Print.

[Elliott, John]. The Travels of Hildebrand Bowman, Esquire, Into Carnovirria, Taupiniera, Olfactaria, and Auditante, in New-Zealand; in the Island of Bonhommica, and in the powerful Kingdom of Luxo-volupto, on the Great Southern Continent. London, 1778.

[Evans, Ambrose]. The Adventures and Surprizing Deliverances, of James Dubourdieu, and His Wife. London, 1719.

Gentleman, Francis. A trip to the Moon: Containing an Account of the Island of Noibla. Its Inhabitants, Religious and Political Customs. Newcastle upon Tyne, 1764.

[Godwin, Francis]. The Man in the Moone; or A Discourse of a Voyage Thither. By Domingo Gonsales. London, 1638.

Hauskeller, Michael. Mythologies of Transhumanism. Cham: Palgrave Macmillan, 2016. Print.

[Kirkby, John]. The Capacity and Extent of the Human Understanding. London, 1745.

L'Epy, M. Heliogenes de. A Voyage into Tartary. Containing a Curious Description of that Country, with part of Greece and Turky; the Manners, Opinions, and Religion of the Inhabitants therein; with some other Incidents. London, 1689. 
[Lupton, Thomas]. Siuqila. Too Good, to be true: Omen. Though so at a vewe, Yet all that I tolde you, Is true, I upholde you: Now cease to aske why For I can not lye. Herein is shewed by waye of Dialogue, the wonderfull maners of the people of Mauqsun, with other talke not frivolous. London, 1580.

More, Thomas. Utopia, ed. Edward Surtz, S.J. and J.H. Hexter, Complete Works of St Thomas More, IV. New Haven, CT: Yale University Press, 1965. Print.

[Northmore, Thomas]. Memoirs of Planetes, or a Sketch of the Laws and Manners of Makar. London, 1795.

Paltock, Robert. The Life and Adventures of Peter Wilkins, A Cornish Man. London, 1751.

Roden, David. Posthuman Life. Philosophy on the Edge of the Human. Abingdon: Routledge, 2015. Print.

Swift, Jonathan. Gulliver's Travels. Ed. Robert A. Greenberg. New York and London: Norton, 1970. Print.

Veiras, Denis. The History of the Sevarambians: A Utopian Novel. Ed. John Christian Laursen and Cyrus Masroori. Albany: State University of New York Press, 2006. Print.

Wolfe, Cary. What Is Poshumanism? Minneapolis, MN: University of Minnesota Press, 2010. Print.

\section{NADCZŁOWIEK, TRANSCZŁOWIEK I POSTCZŁOWIEK WE WCZESNONOWOŻYTNEJ LITERATURZE UTOPIJNEJ}

\section{Streszczenie}

Artykuł przedstawia funkcjonowanie motywów trashumanizmu i posthumanizmu we wczesnonowożytnej literaturze utopijnej, w której istotną rolę odgrywa problematyka naturalnego poszerzania możliwości ludzkiego ciała i umysłu nie tylko poprzez stworzenie idealnych warunków społeczno-politycznych, ale również dzięki odpowiedniej diecie oraz zdrowemu i wysoce moralnemu stylowi życia. Nowe technologie i wynalazki mogą przyczyniać się do poprawy warunków życia, ale nie prowadzą do radykalnej rewizji tradycyjnej wizji człowieka. Przedstawiane w niektórych utopiach społeczności transludzkie i postludzkie nie stanowią wzorców przyszłego rozwoju ludzkości, pełniąc wyłącznie rolę satyryczną, bądź funkcjonując jako elementy sensacyjne zwiększające atrakcyjność utworów, w których występują.

Słowa kluczowe: wczesnonowożytna literatura utopijna; humanizm; transhumanizm; posthumanizm. 
